\title{
STUDIES ON HUMORAL IMMUNE RESPONSE IN LEPROSY
}

\author{
MITSUO YOKOYAMA ${ }^{122)}$, C. HOWARD TSENG ${ }^{2)}$, WILLIAM T. CHAO ${ }^{22}$, \\ MICHAEL J. O'DONNELL ${ }^{2)}$, JOSEPH C. HATHWAY') \\ AND STEBBINS B. CHANDOR ${ }^{4)}$
}

Department of Immunology, Kurume University School of Medicine, Kurume, 830, Japan" ${ }^{1)}$ Departments of Pathology and Microbiology, University of Illinois at the Medical Center Chicago, Illinois, 606802), Windward Medical Center, Kailua, Hawaii, 867343), and Department of Pathology, Health Science Center, State University of New York at Stony Brook, New York, 11794, U.S.A. ${ }^{4)}$

Received for publication October 26, 1979

\begin{abstract}
Our study was undertaken to determine if the humoral immune status of leprosy patients varied with either the type of the disease or the geographic location of the disease. Another variable investigated was whether or not treatment versus non-treatment had any selected effect on the humoral immune status. Serum immunoglobulin levels were determined by single radial immunodiffusion and other immunoserologic profile testing was performed whenever possible. Immunoglobulin levels did show a difference between the different disease types of leprosy and the authors also feel that environmental and genetic factors may play a more significant role than previously thought.
\end{abstract}

\section{INTRODUCTION}

A method to study the various ways in which individuals respond to infections is to use an actual disease as a model to determine the nature of these reactions. Leprosy is an excellent example for the above type of study since two major forms are well established and patients often present a third transitional form as well. The most common responses to the infectious agent of this disease are lesions abounding with organisms as in the lepromatous patient or lesions where it is extremely difficult to detect the causative organism as in the tuberculoid patient. Since the infectious agent itself does not appear to differ in the two forms, it is more likely that the host response is the major determining factor as to which form will be apparent clinically in the individual. Studies which include an evaluation of immunoglobulin ( $\mathrm{Ig}$ ) levels in leprosy (Lim and Fusaro, 1964, 1968a, 1968b, 1968c, '1976 ; Sheagren, 1969) have been directed at this problem. In the last decade some of the newer thoughts and investigative techniques regarding immune systems in man have enhanced our ability to study leprosy. Recent studies have shown that patients with lepromatous leprosy have an immunological deficit and this abnormality is featured by a deficiency of cell-mediated immunity which selectively involves T cells (Bullock, 1968, 1971; Dierks and Shepherd, 1968 ; Dwyer et al., 1973 ; Godal et al., 1971, 1972 ; Katz et al., 1971; Saha and Mittal, 1971; Sharma and Shrivastav, 1958; Shepard, 1968 ; Talwar, 1972 ; Turk and Waters, 1969, 
1970 ; Waldorf et al., 1969).

The present study was undertaken to review whether humoral immune status of patients with leprosy differs in patients with different clinicohistological types of the disease and from different geographic areas of the world. We were also interested to know whether or not serum immunoglobulin patterns varied in patients with or without an appropriate treatment. When sufficient material was available, other immunoserologic profile testing was performed to find any correlative disease pattern within the leprosy population.

\section{MATERIALS AND METHODS}

Venous blood was obtained from 83 patients at Hale Mahalu Hospital*, Oahu, Hawaii, and serum was separated from clotted blood. Other serum samples, in dry ice, were sent by air mail from the National Leprosy Center, India (20 samples), the National Institute for Leprosy Research, Tokyo (49 samples), and the National Leprosy Colony, Okinawa (30 samples). All sera were stored at $-20^{\circ} \mathrm{C}$ prior to use. Control sera consisting of 10 samples from donors of each sex with ages ranging from 20 to 65 were also obtained from the same geographic areas.

Serum immunoglobulin ( $\operatorname{IgG}, \operatorname{Ig} \mathrm{A}$, $\operatorname{Ig} \mathrm{M}$ and $\mathrm{IgD}$ ) levels were measured by a single radial immunodiffusion test using commercial kits from Kallastad Laboratories (Cheska, Minnesota). IgE values were determined by radioimmunoassay using a kit (Phadebas ${ }^{\mathrm{R}}$ ) from Pharmacia Diagnostic (Piscataway, New Jersey). Screening for rheumatoid factor (RF) was carried out by a latex slide test using the method described by the manufacturer Hyland Laboratories (Costa Mesa, California). Antinuclear autibody (ANA) assays were done by immunofluorescent antibody techniques using the kits of Meloy Laboratories (Springfield, Virginia). Antithyroglobulin antibody (ATA) test was carried out based upon passive hemagglutination method using thyroglobulin-coated red blood cells Wellcome Reagents (Research Triangle Park, North Carolina). Antibodies to gangliosides (A-Ggs) were detected by a passive hemagglutination technique described by one of the authors (GajlPecgalska et al., 1973; Nelson, 1973) which was modified by using a microtiter plate. Sera were also tested for hepatitis B antigen (HBsAg) and its antibody by RIA (Austria II) method using a kit from Abbott Laboratories (North Chicago, Illinois).

\section{RESULTS}

The patients from Hawaii were the most extensively studied because of the availability of more detailed historical and clinical information and the availability of fresh and adequate blood samples for the present analyses. The overall patient population was classified as to sex, age, race, geographic origin with references to the type of disease, either lepromatous (Lep), tuberculoid (Tub), or indeterminate (Ind), as shown in Table 1. Lepromatous cases were found overall to be 3 times more common than cases of the tuberculoid type. Raciald istribution with types of the disease in the 83 Hawaiian cases were classified as follows as shown in Table 2. Twenty-two Hawaiian (19 lepromatous, 1 tuberculoid, and 3 indeterminate), and 8 Samoan, 5 Japanese, 4

* This Hospital was closed subsequent to this study. 
TABLE 1

Number of samples obtained from different geographic areas distributed according to sex and type of leprosy

\begin{tabular}{l|c|c|c|c|c|c|c}
\hline \multirow{2}{*}{ Area } & \multirow{2}{*}{$\begin{array}{c}\text { No. of } \\
\text { Cases }\end{array}$} & \multicolumn{2}{|c|}{ Lepromatous } & \multicolumn{2}{c|}{ Tuberculoid } & \multicolumn{2}{c}{ Indeterminate } \\
\cline { 3 - 7 } \cline { 5 - 7 } & Male & Female & Male & Female & Male & Female \\
\hline Hawaii & 83 & 48 & 25 & 1 & 1 & 3 & 5 \\
India & 20 & 12 & 0 & 7 & 1 & 0 & 0 \\
Tokyo & 49 & 18 & 9 & 11 & 11 & 0 & 0 \\
Okinawa & 30 & 13 & 7 & 10 & 0 & 0 & 0 \\
\hline
\end{tabular}

TABLE 2

Racial distribution and types of leprosy in Hawaiian cases

\begin{tabular}{l|c|c|c|c}
\hline \multicolumn{1}{c|}{ Race } & No. of Cases & Lepromatous & Tuberculoid & Indeterminate \\
\hline Hawaiian & 22 & 19 & 0 & 3 \\
Mixed & 16 & 13 & 1 & 2 \\
Filipino & 24 & 20 & 1 & 3 \\
Samoan & 8 & 8 & 0 & 0 \\
Japanese & 5 & 5 & 0 & 0 \\
Portugese & 4 & 4 & 0 & 0 \\
Chinese & 2 & 2 & 0 & 0 \\
Micronesian & 1 & 1 & 0 & 0 \\
Korean & 1 & 1 & 0 & 8 \\
\hline Total & 83 & 73 & 2 & 0 \\
\hline
\end{tabular}

Portuguese, 2 Chinese, 1 Micronesian, and 1 Korean (all lepromatous). In addition to the racial background of the Hawaiian patients, it was noted that 31 patients were immigrants who had migrated from the Phillippines (23 patients) or from Samoa (8 patients). Among the immigrants, a six month residence in Hawaii was the shortest, with most of the patients residing over 5 years and with 48 years the longest duration of residence. The shortest disease onset after immigration was found at 2 months and the longest at 48 years. The shortest period of time for treatment was 2 months while the longest was 23 years. Most of the patients had been treated with diaminodiphenlysulfone (DDS) and a few cases with Diasone.

The breakdown of the age and type of the disease for all patients is given in Table 3. The total age distribution of the cases in different geographic locations was similar except in India cases where leprosy was found more frequently in younger age groups.

The results of $\mathrm{IgG}$, Ig A, and IgM levels for the patients in the four different geographic areas are given in Table 4 and the results are further broken down into sex groups in Table 5 .

In general, the IgG level of the patients was shown to be higher than the normal group and in particular, IgG in the sera of lepromatous patients from India and Okinawa was found to 
TABLE 3

Distribution of patient's age and type of leprosy

\begin{tabular}{l|l|r|r|r|r|r|r|r|r}
\hline \multirow{2}{*}{ Area } & \multirow{2}{*}{ Type } & \multicolumn{7}{|c}{ Age } & Total \\
\cline { 3 - 10 } & & $11-20$ & $21-30$ & $31-40$ & $41-50$ & $51-60$ & $61-70$ & $<77$ & \\
\hline \multirow{2}{*}{ Hawaii } & Lepromatous & 2 & 11 & 19 & 14 & 18 & 9 & 0 & 73 \\
& Tuberculoid & 0 & 0 & 1 & 0 & 1 & 0 & 0 & 2 \\
& Indeterminate & 0 & 1 & 1 & 3 & 0 & 1 & 2 & 8 \\
\hline \multirow{2}{*}{ India } & Lepromatous & 6 & 1 & 1 & 3 & 1 & 0 & 0 & 12 \\
& Tuberculoid & 5 & 2 & 0 & 1 & 0 & 0 & 0 & 8 \\
& Indeterminate & 0 & 0 & 0 & 0 & 0 & 0 & 0 & 0 \\
\hline \multirow{2}{*}{ Tokyo } & Lepromatous & 1 & 2 & 4 & 12 & 7 & 1 & 0 & 27 \\
& Tuberculoid & 1 & 1 & 4 & 1 & 7 & 4 & 4 & 22 \\
& Indeterminate & 0 & 0 & 0 & 0 & 0 & 0 & 0 & 0 \\
\hline \multirow{2}{*}{ Okinawa } & Lepromatous & 1 & 2 & 1 & 5 & 5 & 3 & 1 & 18 \\
& Tuberculoid & 0 & 6 & 2 & 1 & 0 & 1 & 0 & 10 \\
& Indeterminate & 0 & 0 & 0 & 1 & 0 & 1 & 0 & 2 \\
\hline \multirow{2}{*}{ Total } & & 16 & 26 & 33 & 41 & 40 & 20 & 7 & 182 \\
\hline
\end{tabular}

TABLE 4

Distribution of immunoglobulin levels ( $\mathrm{mg} \%$ ) in different types of leprosy in different geographic areas

\begin{tabular}{c|l|c|c|c|c}
\hline Area & \multicolumn{1}{|c|}{ Type } & No. tested & I g G & I g A & I g M \\
\hline \multirow{2}{*}{ Hawaii } & Lepromatous & 73 & $1628 \pm 390$ & $424 \pm 198$ & $112 \pm 61$ \\
& Tuberculoid & 2 & $1385 \pm 215$ & $490 \pm 100$ & $72 \pm 15$ \\
& Indeterminate & 8 & $1570 \pm 586$ & $548 \pm 189$ & $112 \pm 28$ \\
& Control & 20 & $1140 \pm 328$ & $198 \pm 85$ & $107 \pm 47$ \\
\hline \multirow{2}{*}{ India } & Lepromatous & 12 & $2628 \pm 608$ & $391 \pm 183$ & $345 \pm 176$ \\
& Tuberculoid & 8 & $1618 \pm 249$ & $343 \pm 112$ & $120 \pm 82$ \\
& Indeterminate & 0 & - & - & - \\
& Control & 20 & $1247 \pm 314$ & $224 \pm 92$ & $152 \pm 78$ \\
\hline \multirow{2}{*}{ Tokyo } & Lepromatous & 27 & $1677 \pm 342$ & $441 \pm 201$ & $145 \pm 82$ \\
& Tuberculoid & 22 & $1569 \pm 543$ & $321 \pm 188$ & $-50 \pm 58$ \\
& Indeterminate & 0 & - & - & - \\
& Control & 20 & $1278 \pm 151$ & $256 \pm 69$ & $134 \pm 45$ \\
\hline \multirow{2}{*}{ Okinawa } & Lepromatous & 18 & $2357 \pm 712$ & $568 \pm 233$ & $249 \pm 180$ \\
& Tuberculoid & 10 & $1678 \pm 500$ & $-446 \pm 159$ & - \\
& Indeterminate & 0 & - & - & - \\
& Control & 20 & $1314 \pm 188$ & $243 \pm 12$ & $138 \pm 6$ \\
\hline
\end{tabular}

be markedly elevated when compared to the sera from other areas. The sera of the patients from Hawaii and Tokyo did not show significant differences in the IgG level among the three leprosy types and between the sexes. However, in the lepromatous types in both sexes from Okinawa and in the male cases of India, the IgG levels were higher than for the other leprosy types.

Ig:A values were significantly higher in leprosy patients than in normal groups and varied with different types of the disease, with the sexes, and with the different geographic areas.

IgM levels were found to vary with 
TABLE 5

Distribution of immunoglobulin in levels ( $m g \%)$ in different types of leprosey, sexes, and in geographic areas

\begin{tabular}{|c|c|c|c|c|c|c|}
\hline Area & Type & Sex & No. tested & I g G & Ig A & I g M \\
\hline \multirow[t]{4}{*}{ Hawaii } & Lepromatous & $\frac{\mathrm{M}}{\mathrm{F}}$ & $\begin{array}{l}48 \\
25\end{array}$ & $\begin{array}{l}1651 \pm 401 \\
1584 \pm 343\end{array}$ & $\begin{array}{l}427 \pm 202 \\
419 \pm 196\end{array}$ & $\begin{array}{l}106 \pm 65 \\
124 \pm 51\end{array}$ \\
\hline & Tuberculoid & $\frac{\mathrm{M}}{\mathrm{F}}$ & $\begin{array}{l}1 \\
1\end{array}$ & $\begin{array}{l}1600 \\
1170\end{array}$ & $\begin{array}{l}509 \\
390\end{array}$ & $\begin{array}{l}56 \\
87\end{array}$ \\
\hline & Indeterminate & $\frac{\mathrm{M}}{\mathrm{F}}$ & $\begin{array}{l}3 \\
5\end{array}$ & $\begin{array}{l}1430 \pm 553 \\
1654 \pm 252\end{array}$ & $\begin{array}{l}520 \pm 200 \\
565 \pm 180\end{array}$ & $\begin{array}{l}103 \pm 29 \\
117 \pm 25\end{array}$ \\
\hline & Control & $\frac{\mathrm{M}}{\mathrm{F}}$ & $\begin{array}{l}10 \\
10\end{array}$ & $\begin{array}{l}1250 \pm 280 \\
1330 \pm 320\end{array}$ & $\begin{array}{l}210 \pm 68 \\
276 \pm 72\end{array}$ & $\begin{array}{l}112 \pm 37 \\
132 \pm 32\end{array}$ \\
\hline \multirow[t]{4}{*}{ India } & Lepromatous & $\frac{\mathrm{M}}{\mathrm{F}}$ & $\begin{array}{r}12 \\
0\end{array}$ & $2628 \pm 608$ & $391 \pm 183$ & $345 \pm 176$ \\
\hline & Tuberculoid & $\frac{\mathrm{M}}{\mathrm{F}}$ & $\begin{array}{l}7 \\
1\end{array}$ & $\begin{array}{l}1616 \pm 268 \\
1630\end{array}$ & $\begin{array}{l}332 \pm 117 \\
420\end{array}$ & $\begin{array}{l}113 \pm 86 \\
170\end{array}$ \\
\hline & Indeterminate & $\begin{array}{l}\mathrm{M} \\
\mathrm{F}\end{array}$ & $\begin{array}{l}0 \\
0\end{array}$ & $=-$ & $=-$ & $=-$ \\
\hline & Control & $\frac{\mathrm{M}}{\mathrm{F}}$ & $\begin{array}{l}10 \\
10\end{array}$ & $\begin{array}{l}1680 \pm 580 \\
1840 \pm 620\end{array}$ & $\begin{array}{l}280 \pm 78 \\
320 \pm 82\end{array}$ & $\begin{array}{l}127 \pm 69 \\
134 \pm 80\end{array}$ \\
\hline \multirow[t]{4}{*}{ Tokyo } & Lepromatous & $\frac{\mathrm{M}}{\mathrm{F}}$ & $\begin{array}{r}18 \\
9\end{array}$ & $\begin{array}{l}1493 \pm 310 \\
1942 \pm 193\end{array}$ & $\begin{array}{l}552 \pm 155 \\
558 \pm 170\end{array}$ & $\begin{array}{l}142 \pm 85 \\
322 \pm 75\end{array}$ \\
\hline & Tuberculoid & $\frac{\mathrm{M}}{\mathrm{F}}$ & $\begin{array}{l}10 \\
12\end{array}$ & $\begin{array}{l}1703 \pm 422 \\
1518 \pm 124\end{array}$ & $\begin{array}{l}428 \pm 219 \\
327 \pm 82\end{array}$ & $\begin{array}{r}112 \pm 51 \\
89 \pm 30\end{array}$ \\
\hline & Indeterminate & $\frac{\mathrm{M}}{\mathrm{F}}$ & $\begin{array}{l}0 \\
0\end{array}$ & $\begin{array}{l}- \\
-\end{array}$ & $\overline{-}=$ & $=-$ \\
\hline & Control & $\frac{\mathrm{M}}{\mathrm{F}}$ & $\begin{array}{l}10 \\
10\end{array}$ & $\begin{array}{l}1235 \pm 180 \\
1307 \pm 261\end{array}$ & $\begin{array}{l}243 \pm 75 \\
228 \pm 58\end{array}$ & $\begin{array}{l}143 \pm 53 \\
177 \pm 60\end{array}$ \\
\hline \multirow[t]{4}{*}{ Okinawa } & Lepromatous & $\frac{\mathrm{M}}{\mathrm{F}}$ & $\begin{array}{r}13 \\
7\end{array}$ & $\begin{array}{l}2522 \pm 634 \\
2049 \pm 796\end{array}$ & $\begin{array}{l}635 \pm 244 \\
442 \pm 158\end{array}$ & $\begin{array}{l}241 \pm 213 \\
263 \pm 108\end{array}$ \\
\hline & Tuberculoid & $\frac{\mathrm{M}}{\mathrm{F}}$ & $\begin{array}{r}10 \\
0\end{array}$ & $\stackrel{1678 \pm 500}{-}$ & $\stackrel{446 \pm 158}{-}$ & $\underline{143 \pm}+\underline{4}$ \\
\hline & Indeterminate & $\frac{\mathrm{M}}{\mathrm{F}}$ & $\begin{array}{l}0 \\
0\end{array}$ & $=\quad-$ & $=\quad-$ & $=-$ \\
\hline & Control & $\frac{\mathrm{M}}{\mathrm{F}}$ & $\begin{array}{l}10 \\
10\end{array}$ & $\begin{array}{l}1329 \pm 147 \\
1300 \pm 330\end{array}$ & $\begin{array}{l}265 \pm 73 \\
221 \pm 97\end{array}$ & $\begin{array}{l}111 \pm 26 \\
167 \pm 36\end{array}$ \\
\hline
\end{tabular}

the type of disease, sex and geographic areas. In sera from all geographic locations the IgM levels of the lepromatous groups were higher than those of the tuberculoid groups. IgM levels of patients in the indeterminate group were also higher than those of the tuberculoid group.
Most of the serum samples demonstrated no detectable IgD by the method utilized which detects levels of $3 \mathrm{mg} \%$ or more. A few samples showed detectable level but there was no pattern of significant elevation based on the type of leprosy, geographic area, sex or age. 
TABLE 6

IgE levels $(u / m l)$ in sera of lepromatous and tuberculoid leprosy patients from Tokyo and Okinawa

\begin{tabular}{l|l|c|c}
\hline \multirow{2}{*}{ Area } & Type & No. tested & $\begin{array}{r}\text { IgE level } \\
\text { Mean S.D. }\end{array}$ \\
\hline \multirow{2}{*}{ Tokyo } & $\begin{array}{l}\text { Lepromatous } \\
\text { Tuberculoid }\end{array}$ & 27 & $508.9 \pm 456.3$ \\
& Control & 20 & $245.0 \pm 234.0$ \\
\hline \multirow{2}{*}{ Okinawa } & Lepromatous & 20 & $707.5 \pm 645.1$ \\
& $\begin{array}{l}\text { Tuberculoid } \\
\text { Control }\end{array}$ & 10 & $417.0 \pm 405.1$ \\
& Con & 20 & \\
\hline
\end{tabular}

TABLE 7

Comparison of immunoglobulin levels between twelve Indian lepromatous and tuberculoid patients with and without treatment

\begin{tabular}{|c|c|c|c|c|}
\hline Type & Treatment & $\mathrm{Ig} \mathrm{G}$ & Ig A & Ig M \\
\hline \multirow[t]{2}{*}{ Lepromatous } & $\begin{array}{l}\text { non-treatment } \\
(\text { Mean } \pm \text { S.D. })\end{array}$ & $\begin{array}{l}2100 \\
1630 \\
3200 \\
(2310 \pm 805.8)\end{array}$ & $\begin{array}{l}240 \\
260 \\
450 \\
(316.7 \pm 115.9)\end{array}$ & $\begin{array}{l}275 \\
350 \\
440 \\
(355 \pm 82.6)\end{array}$ \\
\hline & $\begin{array}{l}\text { treatment } \\
\quad(\text { Mean } \pm \text { S.D. })\end{array}$ & $\begin{array}{l}2800 \\
3600 \\
2500 \\
(2666 \pm 568.6)\end{array}$ & $\begin{array}{l}560 \\
510 \\
295 \\
(455 \pm 140.8)\end{array}$ & $\begin{array}{l}220 \\
215 \\
210 \\
(215 \pm 5)\end{array}$ \\
\hline \multirow[t]{2}{*}{ Tuberculoid } & $\begin{array}{l}\text { non-treatment } \\
(\text { Mean } \pm \text { S.D. })\end{array}$ & $\begin{array}{l}1850 \\
1630 \\
1875 \\
(1785 \pm 134.8)\end{array}$ & $\begin{array}{l}240 \\
420 \\
350 \\
(336.7 \pm 90.7)\end{array}$ & $\begin{array}{l}170 \\
170 \\
109 \\
(149.7 \pm 35.2)\end{array}$ \\
\hline & $\begin{array}{l}\text { treatment } \\
\text { (Mean } \pm \text { S.D.) }\end{array}$ & $\begin{array}{l}1250 \\
1850 \\
1700 \\
(1600 \pm 312.2)\end{array}$ & $\begin{array}{l}260 \\
205 \\
270 \\
(245 \pm 35)\end{array}$ & $\begin{array}{l}62 \\
155 \\
235 \\
(150.7 \pm 86.6)\end{array}$ \\
\hline
\end{tabular}

IgE values were measured only on the Tokyo and Okinawa samples and the results are shown in Table 6. Lepromatous cases showed a higher mean value than the tuberculoid cases.

The IgG, A and M levels of 3 lepromatous and 3 tuberculoid cases which were non-treated are shown in Table 7 and compared with similar treated cases. All of these cases were from India and their ages ranges from 11 to
20 years. Three non-treated cases of the lepromatous type showed a significantly lower value of IgG and IgA with an increased IgM level when compared to the treated cases. In contrast, in the tuberculoid type IgG and Ig:A levels in untreated cases were moderately increased while IgM was in normal ranges in comparison to the treated cases. In all cases, however, whether lepromatous or tuberculoid and whether 
TABLE 8

Various antibodies found in sera of patients with lepromatous leprosy

\begin{tabular}{l|c|c|c|c|c|c}
\hline \multicolumn{1}{c|}{ Area } & Sex & No. tested & R F & A N A & A T A & A-Ggs \\
\hline \multirow{2}{*}{ Hawaii } & M & 48 & 11 & 4 & 8 & 13 \\
& F & 25 & 6 & 2 & 6 & 5 \\
India & M & 12 & 2 & 0 & 0 & 3 \\
\multirow{3}{*}{ Tokyo } & F & 0 & 0 & 0 & 0 & 0 \\
\multirow{2}{*}{ Okinawa } & M & 18 & 1 & 0 & 0 & 2 \\
& F & 9 & 1 & 0 & 0 & 0 \\
& M & 3 & 1 & 1 & 1 & 1 \\
\hline
\end{tabular}

treated or non-treated all immunoglobulin values are elevated when compared to control values.

Tests were done for RF, ANA, ATA and A-Ggs. The results are shown in Table 8. In the sera tested, positive reactions to these antigens were found only in the lepromatous group and in general, were more commonly found in the Hawaiian patients. In the testing for $\mathrm{HBsAg}, 1$ male out of 83 Hawaiian samples, 2 males out of 20 Indian samples, and none of 49 Tokyo and 30 Okinawa samples were positive. Only one serum, from Okinawa, of the total samples, demonstrated antibody to HBsAg. and Tokyo fell within normal values. This data lends support to the findings of Sheagren et al. (1969). The results obtained by Lim and Fuasro (Lim and Fusaro, 1964, 1968a, 1968b, $1968 \mathrm{c}, 1976)$, who reported there is a significant elevation of $\mathrm{IgG}$ and $\mathrm{IgM}$ in lepromatous patients while $\operatorname{IgA}$ values are normal, is in obvious contradiction. Tuberculoid case revealed elevated Ig:G and Ig:A levels while IgM fell within normal limits.

Comparisons of $\mathrm{Ig}$ levels between lepromatous and tuberculoid patients with and without treatment revealed no definite pattern due to treatment or non-treatment. Fusaro (1970) stated the reason for the discrepancy with the report of Sheagren et al. (1969) is based upon the treatment or nontreatment of patients at the time of their Ig evaluation. However, the present authors do not feel the treatment with various medications influence such selected effects on the Ig levels of patients since our results show no such pattern. A conclusive determination cannot be made due to the small number of cases available and our analysis is based only upon the Indian population.

It is possible that the method of $\mathrm{Ig}$ quantitation may have been responsible for the difference in the two previous investigations. Lim and Fusaro (Lim and Fusaro, 1964, 1968a, 1968b, 1968c, 1976) used a capillary tube method while Sheagren et al. (1969) used a single radial immunodiffusion test. However, our present results suggest that genetic and environmental factors may influence Ig levels in immune response against agent (s) or leprosy, in particular, lepromatous type.

The high incidence of autoimmune antibodies such as rheumatoid factor and antinuclear antibody were only found in the lepromatous group. There was not a significant difference seen in the presence of autoantibodies be- 
tween male and female groups. The number of patients from the different geographic areas tested is not comparable, but the Hawaiian group seemed to develop autoantibodies which were not related to age group differences as might be seen in the general population. It could be assumed that environmental factors may influence the humoral immunity in the production of autoantibodies and it could also be anticipated that the alteration of serum protein could occur in chronic diseases which might lead to the formation of autoantibodies.

It is interesting to note that antiganglioside antibody was found predominantly in male groups of lepromatous patients. Yokoyama et al. (1963) have reported that the serum of patients with central nervous system disorders such as multiple sclerosis and amyotrophic lateral sclerosis showed antibody activities against gangliosides although the titer was rather. low. Since leprosy cases have been found to have developed some central nervous system involvement as a chronic type of manifestation, one may wonder if it reflects the same neurological mechanism as these other disorders.

\section{ACKNOWLEDGMENTS}

The authors are indebited to Dr. S. Ishihara of National Suruga Leprosarium, Dr. M. Abe of National Institute for Leprosy Research, Tokyo and Dr. S. Kinjo of Ryukyu Tuberculosis Research Institute, Okinawa for supplying the serum samples. Dr. G. Vyas of the University of California at San Francisco for their special arrangement for obtaining the sera of leprosy patients from National Leprosy Research Institute, India.

\section{REFERENCES}

Bullock, W. E. (1968). Studies of immune mechanisms in leprosy. I. Depression of delayed allergic response to skin test antigen. N. Engl. J. Med, 278, 298-304.

Bullock, W.E. and FASAL, P. (1971). Studies of immune mechanisms in leprosy. III. The role of cellular and humoral factors in impairment of the in vitro immune response. J. Immunol., 106, 888-899.

Dierks, R. E. and Shepherd, C. C. (1968). Effect of phytohemagglutinin and various mycobacterial antigens on lymphocyte cultures from leprosy patients. Proc. Soc. Exp. Biol. Med., 127, 391-395.

Dwyer, J. M., Bullock, W.E. and Fields, J.P. (1973). Disturbance of the blood T:B lymphocyte ratio in lepromatous leprosy. $\mathrm{N}$. Engl. J. Med., 288, 1036-1039.

FUSARO, R.M. (1970). Immunologic reactivity in leprosy. Ann. Intern. Med., 72, 602.

GAJL-PeCgalska, K. J, Lim, S.D, JACobson, R. R. and Good, R.R. (1973). B lymphocytes in lepromatous leprosy. N. Engl. J. Med., 288, $1033-1039$.

Godal, T., Myklestad, B., Samuel, D. R. and MYRVANG, B. (1971). Characterization of the cellular immune defect in lepromatous leprosy: A specific lack of circulating $\mathrm{My}$ cobacterium leprae - reactive lymphocytes. Clin. Exp. Immuno, 9, 821-831.

Godal, T., Myrvang, B., Froland, S. S., Shao, J. and Melaku,G. (1972). Evidence that the mechanism of immunological tolerance('central failure') is operative in the lack of host resistance in lepromatous leprosy. Scand. J. Immunol., 1, 311-321.

KatZ, S. I., DeBetZ,B.H. and Zaias, N. (1971). Production of macrophage inhibitory factor by patients with leprosy. Arch. Dermat, 103, 358-361.

Lim, S.D. and Fusaro, R.M. (1964). Leprosy. I. Beta $2 \mathrm{~A}$ and beta $2 \mathrm{M}$ immunoglobulins in leprosy sera. Arch. Dermat., 89, 86-88.

Lim, S.D. and Fusaro, R.M. (1968 a). Serum immunoglobulin changes in leprosy and tuberculosis in proceeding of the XIII Congress of International Dermatologiae, Vol. 2, ed. by Jadassohn, W. and Schirren, C. G., Berlin, Springer-Verlag, pp. 1332-1333.

Lim, S.D. and FusAro, R.M. (1968 b). Leprosy. IV. The quantitation of immune globulins (IgG, IgA, and $\operatorname{Ig} M$ ) in leprosy sera. Intl. J. Leprosy, 36, 114-153.

Lim, S.D. and FuSARo, R.M. (1968 c). Leprosy. V. A quantitative omparison of immune 
globulines ( $\operatorname{IgG}, \operatorname{Ig} M$, and $\operatorname{Ig} A$ ) in the sera of patients with pulmonary tuberculosis and patients with leprosy, Intl. J. Leprosy, 36, 154-161.

LIM, S. D. and FusARo, R. M. (1976). Leprosy II. $\operatorname{Ig} \mathrm{A}$ and $\operatorname{Ig} \mathrm{M}$ immunoproteins in leprosy sera. Intl. J. Leprosy, 35, 355-361.

NeLson, D. S. (1973). Production by stimulated macrophages of factors depressing lymphocyte transformation. Nature (Lond.), 246, 306-307.

Saha, K. and Mittal, M. M. (1971). A study of cell-mediated immunity in leprosy: Changing trends in immunological spectrum of the disease. Clin. Exp. Immunol., 8, 901-919.

Sharma, K. D. and Shrivastav, J. B. (1958). lymphnodes in leprosy. Intl. J. Leprosy, 26, 41-50.

Sheagren, J.N, Block, J.B., Trautman, J.R. and WolfF, S. M. (1969). Immunologic reactivity in patients with leprosy. Ann. Intern. Med, 70. 295-303.

ShePARD, C. C. (1968). Immunologic suppression in leprosy and its relation to leproma- tous disease. Intl. J. Leprosy, 36, 87-90.

Talwar, G.P, Kirshman, A.D., MEhar, V.L, Blum, E. A. and Pearson, J. M. H. (1972). Evaluation of cell-mediated immune response in untreated cases of leprosy. Clin. Exp. Immunol, 12, 195-203.

TURK, J.L. and WATERS, M.F.R. (1969). Cellmediated immunity in patients with leprosy. Lancet, 2, 243-246.

TURK, J.L. and WATERS, M.F.R. (1971). Immunological significant of changes in lymph nodes across the leprosy spectrum. Clin. Exp. Immunol, 8, 363-376.

Waldorf, D. S., Sheagren, J.N. and Trautman, J.R. (1966). Imparied delayed hypersensitivity in patients with lepromatous leprosy. Lancet, 2, 773-776.

YoKoy Ama, M, Trams, E.G. and Brady, R.O. (1962). Sphingolipid antibodies in sera of animals and patients with central nervous system lesions. Proc. Soc. Exp. Biol. Med., 111, 350-352.

Yokoyama, M, Trams, E.G. and Brady, R.O. (1963). Immunochemical studies with gangliosides. J. Immunol, 90, 372-380. 